\title{
Estimation of growth parameters of body weight and body nutrient deposition in males and females of meat- and laying-type quail using the Gompertz model
}

\author{
Daiane de Oliveira Grieser ${ }^{1 *}$, Simara Márcia Marcato ${ }^{1}$, Antonio Claudio Furlan ${ }^{1}$, Vittor \\ Zancanela ${ }^{1}$, Ana Paula Del Vesco ${ }^{2}$, Eliany Batista ${ }^{1}$, Ana Paula Silva Ton ${ }^{3}$, Taynara Prestes \\ Perine $^{1}$
}

${ }^{1}$ Universidade Estadual de Maringá, Departamento de Zootecnia, Maringá, PR, Brasil.

2 Universidade Federal de Sergipe, Departamento de Zootecnia, Aracaju, SE, Brasil.

${ }^{3}$ Universidade Federal de Mato Grosso, Instituto de Ciências Agrárias e Ambientais, Sinop, MT, Brasil.

\begin{abstract}
The objective of this study was to estimate the growth parameters of body weight and body nutrient deposition in males and females of one meat- (Coturnix coturnix coturnix) and two laying-type quail strains (Coturnix coturnix japonica), designated either yellow or red, using the Gompertz model. A total of 1350 quail from 1 to 42 days of age were used and they were distributed in a completely randomized design, with five replications for each strain. The parameters of body weight and body composition of the quail were analyzed weekly and evaluated using the Gompertz equation; growth rates and body nutrient deposition were evaluated through derivative equations. The three strains evaluated showed differences in their potential, growth rates, and body chemical composition. The composition up to 42 days of age was not sufficient to adjust the fat deposition data using Gompertz. Due to the period evaluated, the Gompertz model allowed to verify that females have higher body growth rates when compared with males of the same strains, with accelerated growth up to 14 and 21 days of age for males and females, respectively. Regarding the laying strain, the red has greater growth, with similar potential in depositing protein and water in the carcass, but they are more precocious in the deposition of these nutrients.
\end{abstract}

Key Words: body protein, development of birds, maturity rate, nonlinear model, weight at maturity

\section{Introduction}

Quail production has been highlighted recently as a promising activity of income for farmers, due to its earliness, high productivity, small initial investment required, and, in particular, its fast financial return (Silva and Costa, 2009). The evolution of this activity can be observed in the increasing flocks and productivity indices that have occurred due to the growing number of scientific studies and the diffusion of technology in this field, such as genetic improvements and advancements regarding the nutrition.

Currently, there are several quail strains that have been genetically improved aiming at producing eggs or meat for commercialization. Sakomura et al. (2011) reported that different strains present different growth rates and

Received: April 4, 2017

Accepted: August 22, 2017

*Corresponding author: daianegrieser@gmail.com

Copyright (C) 2018 Sociedade Brasileira de Zootecnia. This is an Open Access article distributed under the terms of the Creative Commons Attribution License (http://creativecommons.org/licenses/by/4.0/), which permits unrestricted use, distribution, and reproduction in any medium, provided the original work is properly cited. body composition and these differences may affect their nutritional requirements. Therefore, it is necessary to improve production rates and, consequently, decrease production costs by conducting studies on the growth curve for each strain and gender.

Several nonlinear models (Logistic, Brody, Robertson, Richards, Gompertz, and Bertalanffy, among others) have been used to describe animal growth (Fitzhugh Jr. and Taylor, 1976). The Gompertz function has been considered as the most appropriate to determine meat-type quail growth, in terms of weight and age (Drumond et al., 2013; Grieser et al., 2015b; Mota et al., 2015; Rocha-Silva et al., 2016), and Japanese laying quail (Narinc et al., 2010; Grieser et al., 2015b; Finco et al., 2016).

Thus, it becomes important to conduct studies to provide up-to-date growth information, consistent with current quail strains, once these are being constantly improved genetically. These data will provide support to the producers and the industry regarding the prediction of nutritional requirements, ideal slaughter age, production efficiency rates, and knowledge about management and feeding practices, as well as contributing information regarding genetic selection of quail and enabling the 
development of growth models, allowing the adoption of appropriate practices to increase the productivity of birds (Sakomura et al., 2011).

With these aspects in mind, the objective of this study was to estimate the growth parameters of body weight and body nutrient deposition in males and females of one meatand two laying-type quail strains, designated either yellow or red, using the Gompertz model.

\section{Material and Methods}

The following experimental procedure was approved by the local Ethics Committee on the Use of Animals (CEUA) (case no. 061/2012).

A total of 1,350 non-sexed quail, aged one day old were used, distributed in a completely randomized design with three treatments (each treatment corresponded to one quail strain) and five replicates with 80 birds per experimental unit of the meat-type strain (Coturnix coturnix coturnix), 90 birds of the yellow strain (Coturnix coturnix japonica), and 100 birds of the red strain (Coturnix coturnix japonica).

They were housed in a conventional shed, divided into 15 boxes of $5 \mathrm{~m}^{2}$, and each box was considered as an experimental unit. The experimental period was from 1 to 42 days of age. During this period, the animals were raised conventionally, with water and feed ad libitum.

The meat-type strain was a commercial strain and the yellow and red laying strains were from stock that was genetically improved in an animal breeding program.

The formulated diets were based on maize and soybean meal and the values for the chemical composition of feed were considered, as defined by Rostagno et al. (2011), depending on the nutritional requirements of quail at different stages of growth (Table 1).

At 21 days of age, the quail were sexed through sexual dimorphism, the breast of the males having a reddish pigmentation, while females presented dark spots on the chest area. The quail were identified with a numbered band on the right foot (banded at one day of age) and individual weighing took place weekly, allowing the determination of growth curves to be differentiated by gender. For the determination of body growth and nutrient chemical deposition in the quail carcass, the methodology described by Sakomura and Rostagno (2016) was used.

To determine body chemical deposition, birds were slaughtered (from 1 to 42 days of age) at 1, 7, 14, 21, 28, 35 , and 42 days of age, with a total of $30,14,5,4,2,2$, and 2 birds, respectively, per replicate for the meat-type quail strain, and $30,18,8,5,4,3$, and 3 birds, respectively, per replicate for laying quail strains. Prior to slaughter, the quail were selected according to the average weight $( \pm 5 \%)$ of each experimental unit and fasted for $6 \mathrm{~h}$.

After slaughter, the carcasses with feathers and viscera were frozen and ground in an industrial meat grinder. The carcass samples were weighed, homogenized, and dried in a forced-air oven for $72 \mathrm{~h}$ at $55{ }^{\circ} \mathrm{C}$. Later, they were weighed again, ground, and transferred to the laboratory for analytical determinations. The levels of dry matter (DM), mineral matter (MM), ether extract (EE), and crude protein (CP) were evaluated. The methodologies used for these analyses are described in detail by the AOAC (2005).

The nonlinear models evaluated in this experiment were the Gompertz, Logistic, Richards, Von Bertalanffy, and Brody models. The Gompertz model was chosen to describe body growth and body nutrient deposition in males and females of one meat- and two laying-type quail strains (yellow or red) because it presented a lower number of iterations for achieving convergence of the data, a lower residual mean square, and squared sum of the regression residuals (data not shown).

Table 1 - Chemical and energetic composition of diets for meat- and laying-type (yellow and red strains) quail at initial and final growth phases

\begin{tabular}{|c|c|c|c|}
\hline \multirow[b]{2}{*}{ Item } & \multicolumn{2}{|c|}{ Meat-type quail } & \multirow{2}{*}{$\begin{array}{c}\text { Laying quail } \\
1-42 \\
\text { days old }\end{array}$} \\
\hline & $\begin{array}{c}1-14 \\
\text { days old }\end{array}$ & $\begin{array}{c}15-42 \\
\text { days old }\end{array}$ & \\
\hline \multicolumn{4}{|l|}{ Ingredient $(\mathrm{g} / \mathrm{kg})$} \\
\hline Corn & 409.5 & 527.9 & 571.6 \\
\hline Soybean meal (45\%) & 497.4 & 393.1 & 380.5 \\
\hline Soybean oil & 47.5 & 32.5 & 11.0 \\
\hline Dicalcium phosphate & 15.6 & 16.0 & 14.1 \\
\hline Salt & 4.6 & 4.6 & 3.9 \\
\hline Limestone & 3.6 & 2.8 & 11.6 \\
\hline DL-methionine & 6.7 & 6.6 & 1.9 \\
\hline L-lysine HCL & 6.8 & 8.0 & 0.5 \\
\hline L-threonine & 4.2 & 4.1 & 0.9 \\
\hline L-tryptophan & 0.1 & 0.4 & - \\
\hline Vitamin and mineral mixture $^{1}$ & 4.0 & 4.0 & 4.0 \\
\hline \multicolumn{4}{|l|}{ Calculated value } \\
\hline Metabolizable energy (MJ/kg) & 12.54 & 12.70 & 12.15 \\
\hline Crude protein $(\mathrm{g} / \mathrm{kg})$ & 275 & 235 & 220 \\
\hline Calcium $(\mathrm{g} / \mathrm{kg})$ & 6.4 & 6.1 & 9.0 \\
\hline Available phosphorus (g/kg) & 4.1 & 4.1 & 3.7 \\
\hline Sodium $(g / k g)$ & 2.0 & 2.0 & 1.8 \\
\hline Potassium (g/kg) & 10.2 & 8.6 & - \\
\hline Chlorine (g/kg) & 3.1 & 3.1 & - \\
\hline Methionine + digestible cystine $(\mathrm{g} / \mathrm{kg})$ & g) 13.2 & 12.3 & 7.6 \\
\hline Digestible lysine $(\mathrm{g} / \mathrm{kg})$ & 18.7 & 17.3 & 11.2 \\
\hline Digestible threonine $(\mathrm{g} / \mathrm{kg})$ & 12.5 & 11.1 & 7.9 \\
\hline Digestible tryptophan $(\mathrm{g} / \mathrm{kg})$ & 3.0 & 2.8 & - \\
\hline
\end{tabular}

${ }^{1}$ Vitamin and mineral supplementation (guaranteed levels per kilogram of diet): retinol acetate, 18,000 IU; cholecalciferol, $5000 \mathrm{IU}$; dl- $\alpha$-tocopheryl acetate, $16 \mathrm{mg}$; thiamine hydrochloride, $1.12 \mathrm{mg}$; riboflavina, $8 \mathrm{mg}$; pyridoxine hydrochloride, $2.1 \mathrm{mg}$; cyanocobalamin, $20 \mathrm{mcg}$; menadione nicotinamide bisulphite, $4.028 \mathrm{mg}$; D-calcium pantothenate, $16 \mathrm{mg}$; niacin acid, $40 \mathrm{mg}$; choline chloride, $560 \mathrm{mg}$; zinc oxide, $126 \mathrm{mg}$; ferrous sulphate, $98 \mathrm{mg}$; manganese sulphate, $155 \mathrm{mg}$; copper sulphate, $30.624 \mathrm{mg}$; cobaltous sulfate heptahydrate, $0.4 \mathrm{mg}$; potassium iodate, $1.936 \mathrm{mg}$; sodium selenite, $0.508 \mathrm{mg}$; butylated hydroxytoluene, $0.02 \mathrm{mg}$. 
Growth curves and body chemistry deposition were prepared using the following Gompertz model (Gompertz, 1825):

$$
\mathrm{W}_{\mathrm{t}}=\mathrm{W}_{\mathrm{m}} \cdot \exp (-\exp (-\mathrm{B}(\mathrm{t}-\mathrm{t} *)))
$$

in which $\mathrm{W}_{\mathrm{t}}$ is the weight at time $\mathrm{t}($ in $\mathrm{g}) ; \mathrm{W}_{\mathrm{m}}$ is the weight at maturity $(\mathrm{g})$; $\mathrm{B}$ is the maturity rate $\left(\mathrm{d}^{-1}\right)$; and $\mathrm{t}^{*}$ is the time (d) of maximal growth (inflection point).

The parameters estimated by the Gompertz equation, separately for each gender and strain, were subjected to analysis of variance using the ANOVA procedure of SAS (Statistical Analysis System, version 9.4), according to the statistical model:

$$
\mathrm{Y}_{i j k}=u+\mathrm{L}_{k}+\mathrm{S}_{j}+(\mathrm{L} \times \mathrm{S})_{k j}+\mathrm{e}_{i j k}
$$

in which $\mathrm{Y}_{i j k}$ are variables of birds of the replication $i$, gender $j$, and strain $k$; $u$ is the mean (F-test $(5 \%)) ; \mathrm{L}_{k}$ is the effect of strain $k$; $\mathrm{S}_{j}$ is the effect of gender $j ;(\mathrm{L} \times \mathrm{S})_{k j}$ is the effect of the interaction strain $k$ with gender $j$; and $\mathrm{e}_{i j k}$ is the error associated with each observation.

\section{Results}

There was interaction $(\mathrm{P}<0.05)$ between strain and gender for body weight (Figure 1a) for $\mathrm{W}_{\mathrm{m}}, \mathrm{B}$, and $\mathrm{t}^{*}$ (Table 2). For the laying quail, there were significant differences $(\mathrm{P}<0.05)$ between strains for the parameters $\mathrm{W}_{\mathrm{m}}$ (red $>$ yellow), B (red $>$ yellow), and t* (red males $>$ yellow males and red females $<$ yellow females) for body weight.
For the three strains, there was a significant difference $(\mathrm{P}<0.05)$ between genders in $\mathrm{W}_{\mathrm{m}}$ (females $>$ males), $\mathrm{B}$ (males $>$ females), and parameter $t^{*}$ (females $>$ males). The fact that females showed a lower B and a greater $t^{*}$ than males for body weight indicates that males are earlier in reaching maximum body growth age $\left(\mathrm{t}^{*}\right)$.

Body growth rates were different between strains and gender (Figure 1b). Meat-type males presented the maximum growth rate at 14 days (7.73); thus, they were more precocious than meat-type females, which reached their maximum body development at 21 days of age (8.34) (Table 3). Meat-type females showed a slower drop in the growth curve after the inflection point, indicating that they have greater body growth potential than meat-type males.

Laying males showed the greatest growth rates from 7 to 28 days of age and females, from 7 to 35 days. Among the laying strains, the red presented the greatest growth rates (males, 4.33 and females, 4.52), with the exception from one to six days of age for yellow males.

It was not possible to adjust the body fat deposition curve using the Gompertz model (Table 4) with the data obtained weekly from 1 to 42 days of age of the chemical composition of body fat in males and females of the three quail strains. However, it was observed that the body fat percentage increased with age in meat- and laying-type quail (Table 5).

\begin{tabular}{|c|c|c|c|c|c|c|c|c|c|c|}
\hline & \multirow{2}{*}{ Strain } & \multicolumn{2}{|c|}{$\mathrm{W}_{\mathrm{m}}(\mathrm{g})$} & \multirow{2}{*}{ Mean } & \multicolumn{2}{|c|}{$\mathrm{B}\left(\mathrm{day}^{-1}\right)$} & \multirow{2}{*}{ Mean } & \multicolumn{2}{|c|}{$\mathrm{t} *$ (days) } & \multirow{2}{*}{ Mear } \\
\hline & & Male & Female & & Male & Female & & Male & Female & \\
\hline \multirow{3}{*}{ Body weight } & Meat-type & $275 \pm 6.0 \mathrm{Ba}$ & $369 \pm 12.6 \mathrm{Aa}$ & $321.9 \mathrm{a}$ & $0.079 \pm 0.002 \mathrm{Ac}$ & $0.061 \pm 0.002 \mathrm{Ba}$ & $0.070 \mathrm{a}$ & $16.9 \pm 0.3 \mathrm{Ba}$ & $21.1 \pm 0.8 \mathrm{Ac}$ & $19.0 \mathrm{a}$ \\
\hline & Yellow & $131 \pm 2.1 \mathrm{Bc}$ & $204 \pm 9.4 \mathrm{Ac}$ & $167.5 \mathrm{c}$ & $0.082 \pm 0.001 \mathrm{Ab}$ & $0.054 \pm 0.003 \mathrm{Bc}$ & $0.068 \mathrm{~b}$ & $14.9 \pm 0.2 \mathrm{Bc}$ & $22.3 \pm 1.2 \mathrm{Aa}$ & $18.6 \mathrm{c}$ \\
\hline & Red & $144 \pm 5.0 \mathrm{Bb}$ & $215 \pm 10.2 \mathrm{Ab}$ & $179.6 \mathrm{~b}$ & $0.083 \pm 0.003 \mathrm{Aa}$ & $0.057 \pm 0.002 \mathrm{Bb}$ & $0.070 \mathrm{a}$ & $15.8 \pm 0.6 \mathrm{Bb}$ & $21.8 \pm 1.0 \mathrm{Ab}$ & $18.8 \mathrm{~b}$ \\
\hline
\end{tabular}

Table 2 - Estimated values of the Gompertz equation parameters for body weight in meat- and laying-type (yellow and red strains) quail

$\mathrm{W}_{\mathrm{m}}$ - maturity weight; $\mathrm{B}$ - maturity rate; $\mathrm{t}^{*}$ - time to maximal growth.

$\mathrm{ab}$ - Within a column, values not sharing a common lowercase letter are significantly different $(\mathrm{P} \leq 0.05)$.

$\mathrm{AB}$ - Mean values within the same row not sharing a common uppercase letter are statistically different at $\mathrm{P}<0.05$.

(a)

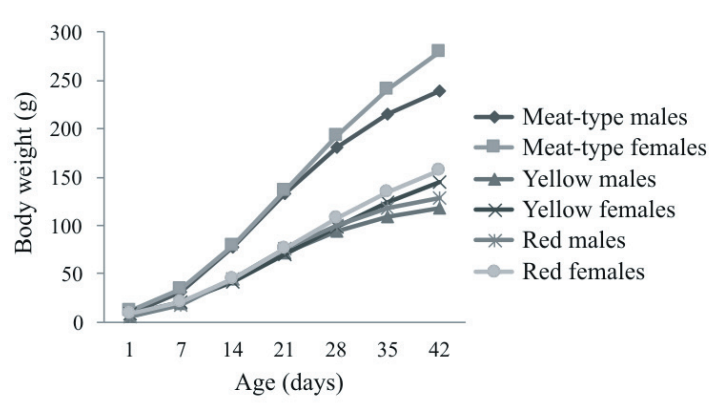

(b)

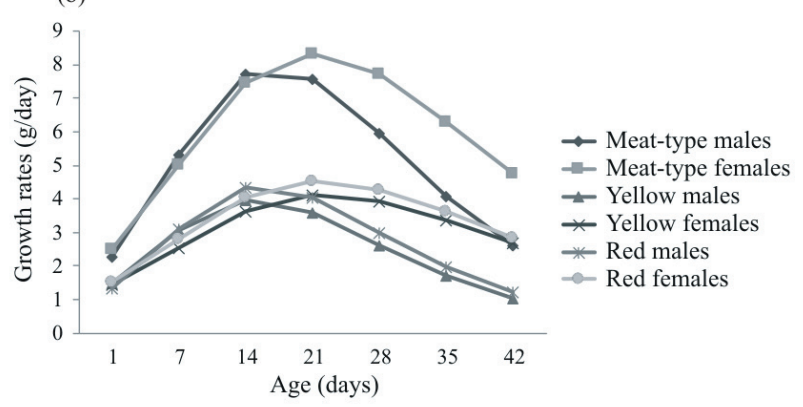

Figure 1 - Growth curves (a) and deposition rates (b) of body weight of meat- and laying-type (yellow and red strains) quail. 
For laying quail, there were significant differences $(\mathrm{P}<0.05)$ among strains for the parameters $\mathrm{W}_{\mathrm{m}}$ for body ash (yellow with greater value than the red strain), B for water, ash, and body crude protein (yellow with lower value than the red strain), and $t^{*}$ for water and body ash (yellow with greater value than the red strain) (Table 4). For laying quail, there were no significant differences $(\mathrm{P}>0.05)$ between strains for the parameters $\mathrm{W}_{\mathrm{m}}$, for the variables water and body crude protein, and for $\mathrm{t}^{*}$, for the variable body crude protein. The fact that the yellow strain showed a lower B and a greater $t^{*}$ than the red strain for water and body ash indicates that the red is earlier in reaching the maximum body growth age $\left(t^{*}\right)$.

Table 3 - Values of live weight and parameter estimates of the Gompertz equation derived for body weight in meatand laying-type (yellow and red strains) quail

\begin{tabular}{|c|c|c|c|c|c|c|}
\hline \multirow{2}{*}{ Age (days) } & \multicolumn{2}{|c|}{ Meat-type } & \multicolumn{2}{|c|}{ Yellow } & \multicolumn{2}{|c|}{ Red } \\
\hline & Male & Female & Male & Female & Male & Female \\
\hline \multicolumn{7}{|c|}{ Live weight (g/bird) } \\
\hline 1 & 8.86 & 8.80 & 7.34 & 7.17 & 7.48 & 7.36 \\
\hline 7 & 31.36 & 32.61 & 20.29 & 20.15 & 19.37 & 20.48 \\
\hline 14 & 78.20 & 81.60 & 42.72 & 42.42 & 42.90 & 45.04 \\
\hline 21 & 131.41 & 137.67 & 71.19 & 70.75 & 73.50 & 76.95 \\
\hline 28 & 182.24 & 190.40 & 96.03 & 97.53 & 102.63 & 107.41 \\
\hline 35 & 216.09 & 236.61 & 109.47 & 122.18 & 119.73 & 130.79 \\
\hline 42 & 238.11 & 282.79 & 116.52 & 145.73 & 125.32 & 158.74 \\
\hline \multicolumn{7}{|c|}{ Body growth rate (g/bird day) } \\
\hline 1 & 2.29 & 2.51 & 1.47 & 1.44 & 1.35 & 1.51 \\
\hline 7 & 5.32 & 5.01 & 3.06 & 2.55 & 3.12 & 2.79 \\
\hline 14 & 7.73 & 7.47 & 3.98 & 3.64 & 4.33 & 4.03 \\
\hline 21 & 7.59 & 8.34 & 3.58 & 4.10 & 4.04 & 4.52 \\
\hline 28 & 5.95 & 7.71 & 2.62 & 3.94 & 3.01 & 4.28 \\
\hline 35 & 4.09 & 6.31 & 1.70 & 3.39 & 1.97 & 3.62 \\
\hline 42 & 2.61 & 4.76 & 1.04 & 2.70 & 1.21 & 2.84 \\
\hline
\end{tabular}

Table 4 - Estimated values of the Gompertz equation parameters for body composition (water, ash, and crude protein) in meat- and laying-type (yellow and red strains) quail

\begin{tabular}{lccc}
\hline Strain & $\mathrm{W}_{\mathrm{m}}(\mathrm{g})$ & $\mathrm{B}\left(\right.$ day $\left.^{-1}\right)$ & $\mathrm{t} *($ day $)$ \\
\hline \multicolumn{4}{c}{ Body water } \\
Meat-type & $183 \pm 11.36 \mathrm{a}$ & $0.084 \pm 0.010 \mathrm{~b}$ & $15.6 \pm 1.16 \mathrm{a}$ \\
Yellow & $96 \pm 3.98 \mathrm{~b}$ & $0.082 \pm 0.007 \mathrm{~b}$ & $15.1 \pm 0.88 \mathrm{a}$ \\
Red & $97 \pm 6.20 \mathrm{~b}$ & $0.092 \pm 0.009 \mathrm{a}$ & $14.4 \pm 0.95 \mathrm{~b}$ \\
\multicolumn{4}{c}{ Body ash } \\
Meat-type & $22 \pm 5.19 \mathrm{a}$ & $0.051 \pm 0.009 \mathrm{~b}$ & $31.0 \pm 5.79 \mathrm{a}$ \\
Yellow & $12 \pm 6.53 \mathrm{~b}$ & $0.054 \pm 0.010 \mathrm{~b}$ & $30.0 \pm 11.69 \mathrm{a}$ \\
Red & $8 \pm 2.08 \mathrm{c}$ & $0.076 \pm 0.020 \mathrm{a}$ & $21.8 \pm 4.22 \mathrm{~b}$ \\
\multicolumn{4}{c}{ Body crude protein } \\
Meat-type & $70 \pm 8.90 \mathrm{a}$ & $0.064 \pm 0.010 \mathrm{c}$ & $22.2 \pm 2.88 \mathrm{a}$ \\
Yellow & $30 \pm 2.51 \mathrm{~b}$ & $0.076 \pm 0.009 \mathrm{~b}$ & $18.4 \pm 1.80 \mathrm{~b}$ \\
Red & $31 \pm 2.80 \mathrm{~b}$ & $0.085 \pm 0.010 \mathrm{a}$ & $17.8 \pm 1.36 \mathrm{~b}$ \\
\hline
\end{tabular}

$\mathrm{W}_{\mathrm{m}}$ - maturity weight; $\mathrm{B}$ - maturity rate; $\mathrm{t}^{*}$ - time to maximal growth. $\mathrm{ab}-$ Within a column, values not sharing a common lowercase letter are significantly different $(\mathrm{P} \leq 0.05)$.
By the derivative of Gompertz equations for water (Figure 2a), ash (Figure 2c), and crude protein deposition (Figure 2e), growth rates were obtained (Figures 2b, 2d, and $2 \mathrm{f}$, respectively), in grams of weight per day, according to the age of the quail.

The meat-type quail reached the maximum water, ash, and crude protein deposition in carcass at 15,31 , and 22 days of age, (5.61, 0.40, and 1.63) respectively (Table 6). After this age, the weight gain started decreasing. The meat-type strain presented the greatest crude protein deposition rates from 12 to 35 days and after this age, there was a significant decrease in body crude protein deposition. The yellow and red strains had the greatest crude protein deposition rates from 9 to 31 days and from 8 to 31 days of age, respectively. For both yellow and red laying strains, the age of maximum crude protein deposition was similar, at 18.41 and 17.81 , respectively.

Comparing the maximum deposition with the deposition at 35 days of age, we observed a reduced crude

Table 5 - Values of water, ash, crude protein, and body fat in natural matter in meat- and laying-type (yellow and red strains) quail

\begin{tabular}{|c|c|c|c|}
\hline \multirow{2}{*}{ Age (days) } & \multicolumn{3}{|c|}{ Strain } \\
\hline & Meat-type & Yellow & Red \\
\hline \multicolumn{4}{|c|}{ Body water (g/bird day) in natural matter } \\
\hline 1 & 5.51 & 5.35 & 5.23 \\
\hline 7 & 23.95 & 15.02 & 15.08 \\
\hline 14 & 59.54 & 30.21 & 31.63 \\
\hline 21 & 97.73 & 51.12 & 55.59 \\
\hline 28 & 126.32 & 69.10 & 74.68 \\
\hline 35 & 150.07 & 78.68 & 84.26 \\
\hline 42 & 162.99 & 83.96 & 86.63 \\
\hline \multicolumn{4}{|c|}{ Body ash ( $\mathrm{g} /$ bird day) in natural matter } \\
\hline 1 & 0.15 & 0.15 & 0.14 \\
\hline 7 & 0.69 & 0.51 & 0.49 \\
\hline 14 & 2.37 & 1.31 & 1.41 \\
\hline 21 & 4.12 & 2.65 & 2.81 \\
\hline 28 & 6.42 & 3.54 & 3.62 \\
\hline 35 & 9.38 & 5.19 & 5.81 \\
\hline 42 & 11.79 & 6.30 & 5.73 \\
\hline \multicolumn{4}{|c|}{ Body crude protein ( $\mathrm{g} / \mathrm{bird}$ day) in natural matter } \\
\hline 1 & 1.07 & 0.92 & 0.95 \\
\hline 7 & 4.69 & 3.06 & 3.05 \\
\hline 14 & 13.85 & 7.47 & 7.47 \\
\hline 21 & 24.97 & 12.96 & 14.30 \\
\hline 28 & 33.72 & 19.43 & 20.46 \\
\hline 35 & 43.85 & 21.92 & 24.25 \\
\hline 42 & 51.70 & 25.56 & 26.80 \\
\hline \multicolumn{4}{|c|}{ Body fat $(\mathrm{g} / \mathrm{bird}$ day) in natural matter } \\
\hline 1 & 0.43 & 0.46 & 0.43 \\
\hline 7 & 1.36 & 0.81 & 0.78 \\
\hline 14 & 2.93 & 1.27 & 1.61 \\
\hline 21 & 5.52 & 1.97 & 2.41 \\
\hline 28 & 8.67 & 3.46 & 3.96 \\
\hline 35 & 18.82 & 4.04 & 6.32 \\
\hline 42 & 32.86 & 10.29 & 10.42 \\
\hline
\end{tabular}


protein deposition of $41.98 \%(0.492 / 0.848)$ for yellow and $49.95 \%(0.483 / 0.965)$ for red and, moreover, the reduction at 42 days of age was $61.79 \%(0.324 / 0.848)$ for yellow and $69.33 \%(0.296 / 0.965)$ for the red strain. At this point, the yellow strain had the greatest crude protein deposition rates.

In relation to the laying quail, the red strain reached the greatest water and crude protein body deposition rates and they were more precocious regarding body nutrient deposition. However, deposition rates decreased faster after the inflection point of the curve.

\section{Discussion}

Different strains and gender may differ in various aspects, such as mature weight, composition, and body nutrient deposition rates and these aspects may affect the characteristics of the growth curve (Gous et al., 1999).
Meat-type quail achieve greater body growth (live weight at 35 and 42 days of age of 225 and $258 \mathrm{~g}$, respectively) and are used by producers for slaughter purposes ( 35 to 42 days of age). Both yellow and red Japanese laying quail strains present low body weight (live weight at 35 and 42 days of age of 114 and 124; 128 and 139 g, respectively) and are widely used for egg production, going to slaughter at the end of their productive cycle; however, due to the age of slaughter, their meat becomes harder, losing quality (Silva and Costa, 2009; Grieser et al., 2015a).

The genetic improvement of quail depends on the strain: the goal of geneticists for meat-type quail is to try to improve the carcass yield and productive efficiency. For laying quail, the objectives are concentrated on lowering the corporal weight without interfering in egg production and improving their quality and feed conversion per kilo of eggs produced (Grieser et al., 2015b).

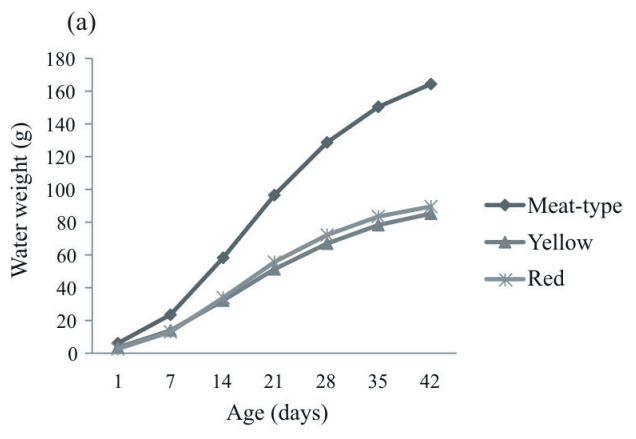

(b)
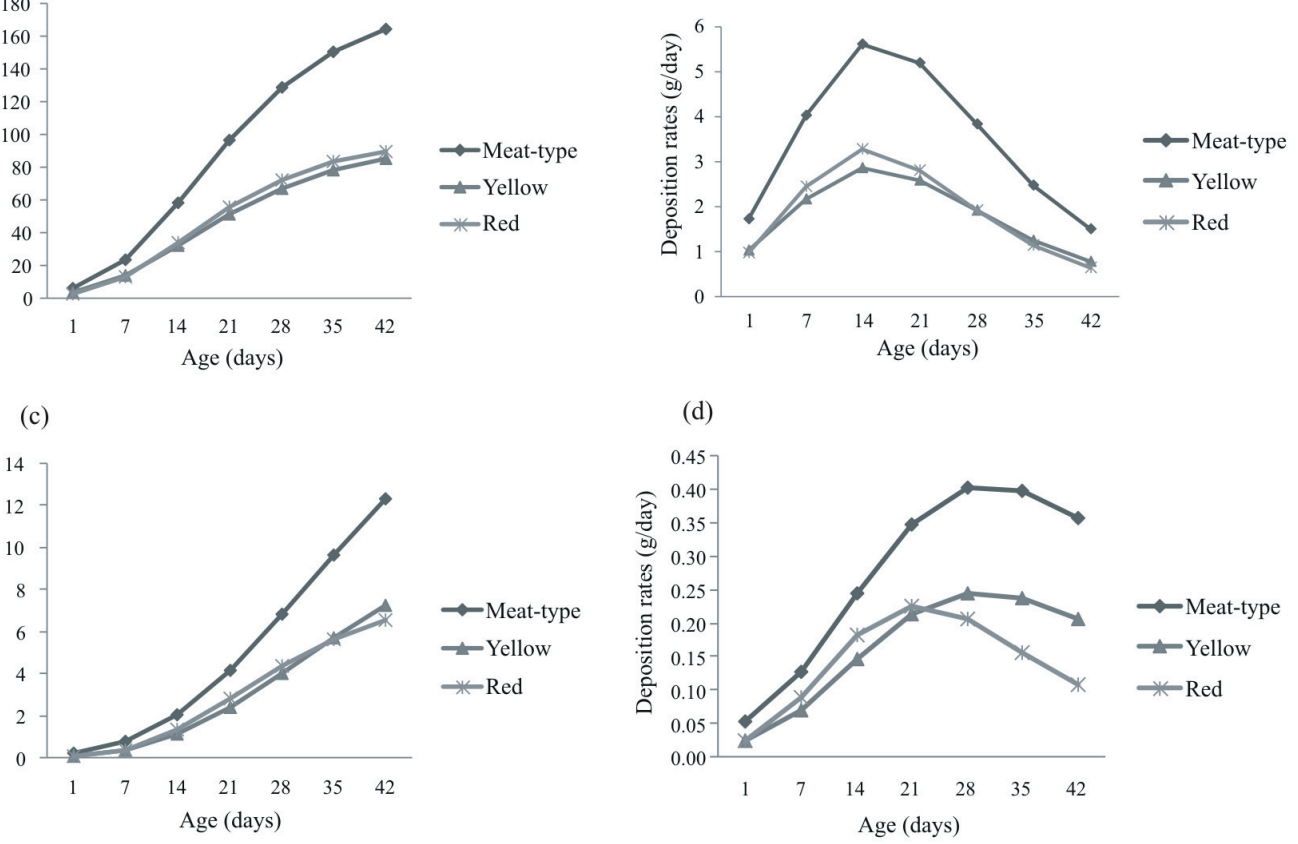

(e)

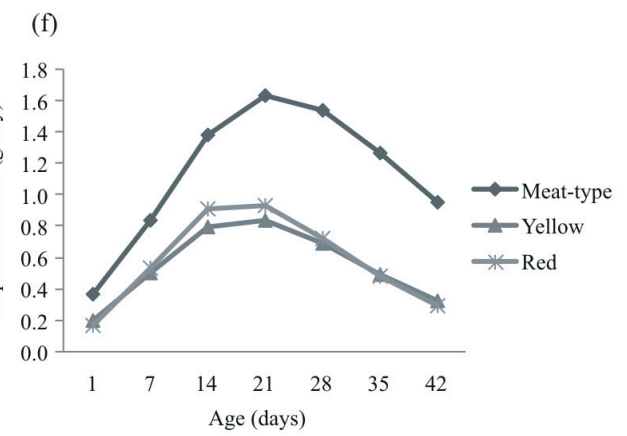

Figure 2 - Growth curves and deposition rates of water (a, b), ash (c, d), and body crude protein (e, f) in meat- and laying-type (yellow or red) quail. 
This description of quail growth may be used as a basis for future genetic selection programs, in addition to the preparation of simulation models that can predict nutritional requirements and determine the effects of different nutritional programs and environmental conditions on animal performance (Gous et al., 1999; Grieser et al., 2015b).

Each animal strain has a different growth curve, which should be analyzed under ideal or non-limiting conditions (Gous et al., 1999). Body growth is determined by the body crude protein, fat, ash, and water deposition. The potential for growth and body chemistry deposition can vary depending on strains, gender, and stage of growth. The growth curves expressing the development of birds under specific conditions can be divided into ascending, plateau, and descending, following a sigmoid growth curve (Sakomura and Rostagno, 2016).

The Gompertz model, unlike other functions that consider the initial body mass as zero, assumes that the animal is already born with some initial body weight (Fialho, 1999). After birth, the growth of birds is accelerated until a certain age represented by the inflection point of the curve (obtained by the $t^{*}$ parameter in the function), at which the growth rate is at its maximum. After this age, birds slowly decrease their growth, gradually reducing the daily gain rates to achieve their mature weight $\left(\mathrm{W}_{\mathrm{m}}\right)$,

Table 6 - Estimated values of the Gompertz equation derived for body composition (water, ash, and crude protein) in meat- and laying-type (yellow and red strains) quail

\begin{tabular}{|c|c|c|c|c|}
\hline \multirow{2}{*}{ Body composition } & \multirow{2}{*}{$\begin{array}{l}\text { Age } \\
\text { (days) }\end{array}$} & \multicolumn{3}{|c|}{ Body deposition rate ( $\mathrm{g} / \mathrm{bird}$ day) } \\
\hline & & Meat-type & Yellow & Red \\
\hline \multirow{7}{*}{ Water } & 1 & 1.74 & 1.05 & 0.99 \\
\hline & 7 & 4.04 & 2.18 & 2.44 \\
\hline & 14 & 5.61 & 2.85 & 3.28 \\
\hline & 21 & 5.18 & 2.60 & 2.82 \\
\hline & 28 & 3.82 & 1.92 & 1.92 \\
\hline & 35 & 2.48 & 1.26 & 1.15 \\
\hline & 42 & 1.51 & 0.78 & 0.65 \\
\hline \multirow{7}{*}{ Ash } & 1 & 0.05 & 0.02 & 0.02 \\
\hline & 7 & 0.13 & 0.07 & 0.09 \\
\hline & 14 & 0.25 & 0.15 & 0.18 \\
\hline & 21 & 0.35 & 0.21 & 0.23 \\
\hline & 28 & 0.40 & 0.24 & 0.21 \\
\hline & 35 & 0.40 & 0.24 & 0.16 \\
\hline & 42 & 0.36 & 0.21 & 0.11 \\
\hline \multirow{7}{*}{ Crude protein } & 1 & 0.36 & 0.20 & 0.17 \\
\hline & 7 & 0.84 & 0.51 & 0.54 \\
\hline & 14 & 1.39 & 0.80 & 0.91 \\
\hline & 21 & 1.63 & 0.83 & 0.93 \\
\hline & 28 & 1.54 & 0.69 & 0.73 \\
\hline & 35 & 1.27 & 0.49 & 0.48 \\
\hline & 42 & 0.95 & 0.32 & 0.30 \\
\hline
\end{tabular}

which causes a growth curve stabilization (Sakomura and Rostagno, 2016). Theoretically, $\mathrm{W}_{\mathrm{m}}$ of function can only be achieved after an infinite time, but can be extrapolated using experimental data (Sakomura and Rostagno, 2016). The other parameter of the function is $\mathrm{B}$, which indicates the relative growth rate, in $\mathrm{d}^{-1}$ by $\mathrm{g}$ of body mass, at the point in which it is considered to be the maximum. Greater $B$ values concentrate the growth close to the inflection point and this is responsible for increasing the maximum growth rate due to a slow initial and final growth. However, lower $B$ values are responsible for a more distributed growth over time (Fialho, 1999).

Similar to this study, Silva and Costa (2009) observed an accelerated growth in quail until 21 days of age, at which point a greater crude protein and water deposition in carcass occurred (Reginatto et al., 2000). After the age of maximum growth, a reduction in increasing body weight gain in quail was observed (Table 3) and this result was also reported by Móri et al. (2005). This probably occurred because a young animal deposits a greater amount of muscle tissue and when it becomes an adult, the muscle deposition and bone growth decrease, resulting in a reduction in the body weight gain rate (Silva et al., 2012; Finco et al., 2016). As they get older, birds present more body fat deposition, which is related to the amount of nutrients (proteins, fats, and carbohydrates) available for synthesis, which is also observed for the majority of animals. Nevertheless, body protein deposition is regulated by genetics and there is a limit to daily deposition, regardless of the nutrition used. The protein and fat deposition are balanced, while the intake capacity is just enough to maintain the growth rates of lean tissue. However, when feed intake is greater than necessary for maximum protein growth, fat deposition usually occurs (Reginatto et al., 2000).

The description of the body growth for meat- and layingtype quail strains demonstrates significant differences due to strains and gender (Table 2). These differences indicate that strains with higher body protein content present greater deposition rates of this component, thus reaching a heavier body weight. From a nutritional standpoint, greater protein deposition directly affects the nutritional requirements of the bird, increasing the need for protein in the diet, and when associated with a lower rate of fat deposition, protein requirements tend to increase at a greater rate than energy requirements. Similarly, birds with a greater fat concentration in the body have a greater energy requirement in the diet to supply the body fat deposition.

Maturity rates (B) obtained for water, crude protein, and ash suggest that these processes occur at similar velocities and earlier in the quail strains evaluated in 
this study. Fat deposition occurs later and more slowly, gradually increasing while deposition rates of other body chemicals tend to decrease. The difficulty of adjusting the data to determine the parameters of the Gompertz equation for body fat deposition in this study may be due to the small amount of fat deposited until 42 days of age in the different quail strains. Therefore, chemical composition in the carcass should be monitored until an older age has been achieved. Finco et al. (2016) also reported that fat deposition in the carcass of Japanese quail (Hybrid Vicami) occurred later, increasing with age, showing less potential to deposit lean tissue in the carcass from 30 days of age. Raji et al. (2015) reported statistically different $(\mathrm{P}<0.001)$ body fat concentration from 16 weeks of age in Japanese laying quail evaluated from the age of 6 to 54 weeks and the concentration differed statistically between genders, in which the females presented the highest rates.

Comparing the growth in meat-type quail in this study (Table 2) with the results observed by Silva and Costa (2009), who worked with mixed batches, those authors related $\mathrm{W}_{\mathrm{m}}$ values $(367.2 \pm 25.5)$ greater than those observed in meat-type quail in this study; moreover, B values (0.0563) were also lower and the quail later $\left(t^{*}=27.51\right)$ than those observed in this study.

In another study conducted with meat-type quail by $\mathrm{Du}$ Preez and Sales (1997), similar results were found when compared with the present study, such as the difference in gender for $\mathrm{W}_{\mathrm{m}}$ (males and females presented 148.0 \pm 3.00 and $191.9 \pm 5.35$, respectively), which shows that males achieved their maximum body gain earlier. Similarly, considering $\mathrm{B}$ values $(0.079$ and 0.061 , for meat-type males and females, respectively) in this study (Table 2), the females were later and presented growth more distributed because maturity rate (B) had a lower value, and the $\mathrm{W}_{\mathrm{m}}$ had higher value for body weight.

Differences for the growth curve parameters in meattype quail occurred as a result of genetic improvements being carried out, which resulted in the current strains. Considering the laying quail, Silva and Costa (2009) and Narinc et al. (2010) observed greater values for maturity weight than those in the present study. These differences between the results obtained may be due to the genetic differences found in Japanese quail strains.

The growth curves observed for the three quail strains evaluated in this study reflected differences in gender from 21 days of age, with the growth of females being greater than that of males. Silva and Costa (2009) also found differences in growth between genders of different quail strains. Usually, in poultry, males have greater weight than females, but the opposite occurs for quail, with the females being heavier than males. This may be explained by the ovaries and greater internal organ weights (liver, proventriculus, and gizzard) and body fat in females. The males have higher back and heart weight (Raji et al., 2015). Abreu et al. (2014), working with quail (LF1), reported that the gender influenced the performance characteristics of hot carcass, chilled carcass, and breast, with males showing the best yields when slaughtered at 42 days of age.

This difference in growth curves of males and females influences the nutritional requirements and, consequently, different feeding managements for gender and quail strains evaluated in the present study should be adopted. The rearing of mixed batches or different strains together affect the production efficiency index and characteristics related to the final product.

When comparing the age of maximum weight gain, at 35 days of age, a reduction in daily weight gain of $24.34 \%$ (6.31/8.34) for meat-type females and 48.55\% (4.09/7.95) for males was found. Considering the same relation at 42 days of age, we observed that females had a lower weight gain $(42.93 \%$; 4.76/8.34) than males $(67.17 \% ; 2.61 / 7.95)$. Females could be slaughtered at 42 days of age due to a smaller reduction in daily weight gain up to this age $(42.93 \%)$, but a large part of the weight gain in females from 28 days of age is due to the development of the reproductive organs to start the laying process. Observing the calculated values from 35 days of age, the daily weight gain showed a sharp drop, indicating that this is the best age to slaughter. Silva et al. (2012) observed a decline in the peak of maximum growth rate in meat-type quail from 27 days of age, which is the age at which quail started to reduce the capacity of lean tissue deposition. For Japanese laying quail (commercial hybrid Vicami), Finco et al. (2016) reported that the highest body growth rates, body protein, and water deposition (inflection point at 16.27, 17.8 , and 14.4 days of age, respectively) occurred earlier when compared with meat-type quail, which are similar to those obtained in the present study, clearly showing that there are differences in the curves of deposition of body nutrients between the meat- and laying-type quail.

\section{Conclusions}

The three strains evaluated show differences in their potential, growth rates, and body chemical composition. The composition up to 42 days of age is not sufficient to adjust the fat deposition data using Gompertz. Due to the period evaluated, the Gompertz model allows to verify that the females have higher body growth rates than males of the same strains, with accelerated growth up to 
14 and 21 days of age for males and females, respectively. Regarding the laying strain, the red has greater growth, with similar potential in depositing protein and water in the carcass, but they are more precocious in the deposition of these nutrients.

\section{References}

Abreu, L. R. A.; Boari, C. A.; Pires, A. V.; Pinheiro, S. R. F.; Oliveira, R. G.; Oliveira, K. M.; Gonçalves, F. M. and Oliveira, F. R. 2014. Influência do sexo e idade de abate sobre rendimento de carcaça e qualidade da carne de codornas de corte. Revista Brasileira de Saúde e Produção Animal 15:131-140.

AOAC - Association of Official Analytical Chemistry. 2005. Official methods of analysis. 18th ed. Washington, DC, USA.

Du Preez, J. J. and Sales, J. 1997. Growth rate of different sexes of the European quail (Coturnix coturnix). British Poultry Science 38:314-315.

Drumond, E. S. C.; Gonçalves, F. M.; Veloso, R. C.; Amaral, J. M.; Balotin, L. V.; Pires, A. V. and Moreira, J. 2013. Curvas de crescimento para codornas de corte. Ciência Rural 43:1872-1877.

Fialho, F. B. 1999. Interpretação da curva de crescimento de Gompertz. EMBRAPA-CNPSA, Concórdia. Comunicado Técnico 237. p.1-4.

Finco, E. M.; Marcato, S. M.; Furlan, A. C.; Rossi, R. M.; Grieser, D. O.; Zancanela, V.; Oliveira, T. M. M. and Stanquevis, C. E. 2016. Adjustment of four growth models through Bayesian inference on weight and body nutrient depositions in laying quail. Revista Brasileira de Zootecnia 45:737-744.

Fitzhugh Jr., H. A. and Taylor, S. C. S. 1976. Analysis of growth curves and strategies for altering their shape. Journal of Animal Science 42:1036-1051.

Gompertz, B. 1825. On the nature of the function expressive of the law of human mortality and on a new method of determining the value of life contingencies. Philosophical Transactions of the Royal Society 115:513-585.

Gous, R. M.; Moran Jr., E. T.; Stilborn, H. R.; Bradford, G. D. and Emmans, G. C. 1999. Evaluation of the parameters needed to describe the overall growth, the chemical growth, and the growth of feathers and breast muscles of broilers. Poultry Science 78:812-821.

Grieser, D. O.; Marcato, S. M.; Furlan, A. C.; Zancanela, V.; Batista, E.; Ton, A. P. S.; Perine, T. P. and Stanquevis, C. E. 2015a. Desempenho e rendimento de carcaça e partes de três diferentes linhagens de codornas. Zootecnia Tropical 33:61-72.
Grieser, D. O.; Marcato, S. M.; Furlan, A. C.; Zancanela, Z.; Ton, A. P. S.; Batista, E.; Perine, T. P.; Pozza, P. C. and Sakomura, N. C. 2015b. Comparison of growth curve parameters of organs and body components in meat- (Coturnix coturnix coturnix) and laying-type (Coturnix coturnix japonica) quail show interactions between gender and genotype. British Poultry Science 56:6-14.

Móri, C.; Garcia, E. A.; Pavan, A. C.; Piccinin, A. and Pizzolante, C. C. 2005. Desempenho e rendimento de carcaça de quatro grupos genéticos de codornas para produção de carne. Revista Brasileira de Zootecnia 34:870-876.

Mota, L. F. M.; Alcantâra, D. C.; Abreu, L. R. A.; Costa, L. S.; Pires, A. V.; Bonafé, C. M.; Silva, M. A. and Pinheiro, S. R. F. 2015. Crescimento de codornas de diferentes grupos genéticos por meio de modelos não lineares. Arquivos Brasileiros de Medicina Veterinária e Zootecnia 67:1372-1380.

Narinc, D.; Karaman, E.; Firat, M. Z. and Aksoy, T. 2010. Comparison of non-linear growth models to describe the growth in Japanese quail. Journal of Animal and Veterinary Advances 9:1961-1966.

Raji, A. O.; Girgiri, A. Y.; Alade, N. K. and Jauro, S. A. 2015. Characteristics and proximate composition of Japanese quail (Coturnix Japonica) carcass in a semi arid area of Nigeria. Trakia Journal of Sciences 2:159-165.

Reginatto, M. F.; Ribeiro, A. M. L.; Kessler, A. M.; Penz Junior, A. and Krabbe, E. L. 2000. Efeito da energia, relação energia: proteína e fase de crescimento sobre o desenvolvimento e composição de carcaça de frangos de corte. Revista Brasileira de Ciência Avícola 2:229-237.

Rocha-Silva, M.; Araujo, C. V.; Pires, A. V.; De Paula, E. J. H.; Ferreira, E. B. and Da Silva, F. G. 2016. Curva de crescimento de codornas de corte por meio de modelos de regressão não-lineares. Archives of Veterinary Science 21:26-00.

Rostagno, H. S.; Albino, L. F. T.; Donzele, J. L.; Gomes, P. C.; Oliveira, R. F.; Lopes, D. C.; Ferreira, A. S.; Barreto, S. L. T. and Euclides, R. F. 2011. Tabelas brasileiras para aves e suínos: composição de alimentos e exigências nutricionais. 2 ed. UFV, DZO, Viçosa, MG.

Sakomura, N. K.; Gous, R. M.; Marcato, S. M. and Fernandes, J. B. K. 2011. A descrition of the growth of major body components of 2 broiler chicken strains. Poultry Science 90:2888-2896.

Sakomura, N. K. and Rostagno, H. S. 2016. Métodos de pesquisa em nutrição de monogástricos. 2 ed. Funep, Jaboticabal.

Silva, J. H. V. and Costa, F. G. P. 2009. Tabela de exigência nutricional de codornas Japonesas e Europeias: Bases para nutrição de codornas. 2 ed. Funep, Jaboticabal.

Silva, J. H. V.; Filho, J. J.; Costa, F. G. P.; Lacerda, P. B.; Vargas, D. G. V. and Lima, M. R. 2012. Exigências nutricionais de codornas. Revista Brasileira de Saúde e Produção Animal 13:775-790. 